\title{
Aleti Tunu Bibi: Contextualizing a New Rock Art Site in East Timor and the Wider Asia-Pacific Region
}

\author{
$\boldsymbol{\Delta} \cdot \boldsymbol{\Delta} \cdot \boldsymbol{\Delta}$ \\ JEAN-CHRISTOPHE GALIPAUD, REBECCA KINASTON, \\ AND DOMINIQUE GUILLAUD
}

\section{INTRODUCTION}

The Asia-Pacific Region has a long tradition of ROCK ART, dating back some 40,000 years to the same period in which the practice first appeared in Europe (Taçon et al. 2014). In Southeast Asia (SEA), hunter-gatherers were making rock art well before the Neolithic. Uranium series dating suggests that hand stencils and paintings in Sulawesi and possibly Timor were made between 20,000 and 40,000 years ago (Aubert et al. 2007; Aubert et al. 2014; Bulbeck 2004; O'Connor et al. 2010; Taçon et al. 2014), and approximately 9000 years ago in East Kalimantan (Borneo) (Chazine 2005; Plagnes et al. 2003). Although rock art definitely occurred in early antiquity in the region, the vast majority of the 440 or so rock art sites in Island Southeast Asia (ISEA) and the western Pacific have been attributed to the Neolithic Austronesian Painting Tradition (APT). Uranium series dating identified some of the rock art attributed to the APT in caves in the far east of East Timor as younger than 6300 B.P., supporting the assumption that some rock art was likely associated with an Austronesian expansion into the region (Aubert et al. 2007).

APT attributions are based on site location, placement of art at the sites, design and technical elements, motif types, stylistic affinities, and the modern distribution of Austronesian languages in relation to the sites (Ballard 1992; Wilson 2004). ${ }^{1}$ In one of the first regional syntheses of rock art sites of western Melanesia, Ballard (1992) identified sites associated with the Austronesian Painting Tradition as generally: 1) close to the coast; and 2) distributed in regions populated in modern times by Austronesianspeaking populations. ${ }^{2}$ Furthermore, rock art at these sites was usually located: 3 ) in relatively inaccessible areas, such as on cliff faces high off the ground, inside caves or rock shelters, or on boulders; and 4) on areas highly visible from the ocean (Ballard 1992).

Jean-Christophe Galipaud is an archaeologist at the Institut de Recherche pour le Développement (IRD) in Paris, France. Rebecca Kinaston is an Assistant Research Fellow in the Department of Anatomy, Otago School of Medical Sciences, University of Otago in Dunedin, New Zealand and a research fellow in the Department of Archaeogenetics, Max Planck Institute for the Science of Human History, Jena, Germany. Dominique Guillaud is a researcher with the Institut de Recherche pour le Développement (IRD) in Paris, France. 
Although these four attributes hold true for many rock art sites across the region, variations have been found in areas such as Vanuatu and East Timor (O'Connor 2003). Regional connections are apparent in some shared design elements and motif styles in these places; however, variation may have occurred over time as a result of local innovation (O'Connor and Oliveira 2007; Wilson 2004; Wilson et al. 2001). The current study focuses on the relevance of Ballard's (1992) categorization of APT sites for rock art sites in Island Southeast Asia in general and, more specifically, for a newly discovered site in East Timor.

Ever since East Timor won independence from Indonesia in 1999, there has been a steady increase in archaeological research in the country. In conjunction with a synthesis of previous rock art recorded by Portuguese and Australian archaeologists in the 1960s and 1970s, O'Connor (2003) reported 9 new sites in East Timor in this journal and an additional new site 4 years later (O'Connor and Oliveira 2007), bringing the total known rock art sites in the country to 16 . Based on currently available literature, we identified at least 27 rock art sites in the country; there are likely more sites located in the far east of Timor that have yet to be described (Glover 1986; Guillaud et al. 2007; Guillaud and Galipaud 2012; O'Connor 2003; O'Connor and Oliveira 2007; O'Connor et al. 2010). Most of the sites detailed in these publications broadly fit the criteria outlined by Ballard for inclusion in the APT, but variations were found in site location (a number were not located in coastal locations) and motif styles (especially those represented on cliff faces and at sites deeper within solutional caves).

Here we present a new rock art site, Aleti Tunu Bibi, located on the island of Atauro, $30 \mathrm{~km}$ across the Wetar Strait from mainland East Timor. The site and motifs are described and interpreted in the context of rock art in Timor and the wider region to discuss inter-connectivity and the potential antiquity of these practices.

\section{THE ALETI TUNU BIBI SITE}

The cave known locally as Aleti Tunu Bibi is located about $1 \mathrm{~km}$ south of the village of Atekru on the southwestern coast of the island of Atauro (08 $8^{\circ} 13.314^{\prime} \mathrm{S}$, $125^{\circ} 32.152^{\prime} \mathrm{E}$ ) (Fig. 1). It is located less than $200 \mathrm{~m}$ from the actual coastline at an altitude of c. $60 \mathrm{~m}$ above sea level, on a narrow uplifted limestone terrace formed during the penultimate Interglacial Period 125,000 years ago (Chappell and Veeh 1978; Ely et al. 2011). It is a small marine cave approximately $8 \mathrm{~m} \times 7 \mathrm{~m}$ and $2.5 \mathrm{~m}$ high at its highest point (Fig. 2). An earthquake in 2013 affected the uplifted terrace and resulted in the collapse of the front part of the cave, partially blocking the entrance. Tree roots growing through cracks in the limestone have led to further structural instability, especially at the mouth of the cave. Inside, areas of calcite have fallen off, likely another result of the earthquake and heat from fires that have been lit too close to the cave walls.

The Aleti Tunu Bibi rock art is mostly positioned on the lower part of the south wall and at the back of the cave, 1 to $1.5 \mathrm{~m}$ above ground (Figs. 3, 4). The rock art in this cave was photographed multiple times over four different field excursions between 2014 and 2015. We found that within the year since the first photographs were taken, calcite deposits had already accumulated over some of the red paintings. We made a complete recording of the rock art during the most recent field season (August 2015) in correspondence with excavation of archaeological deposits in the 

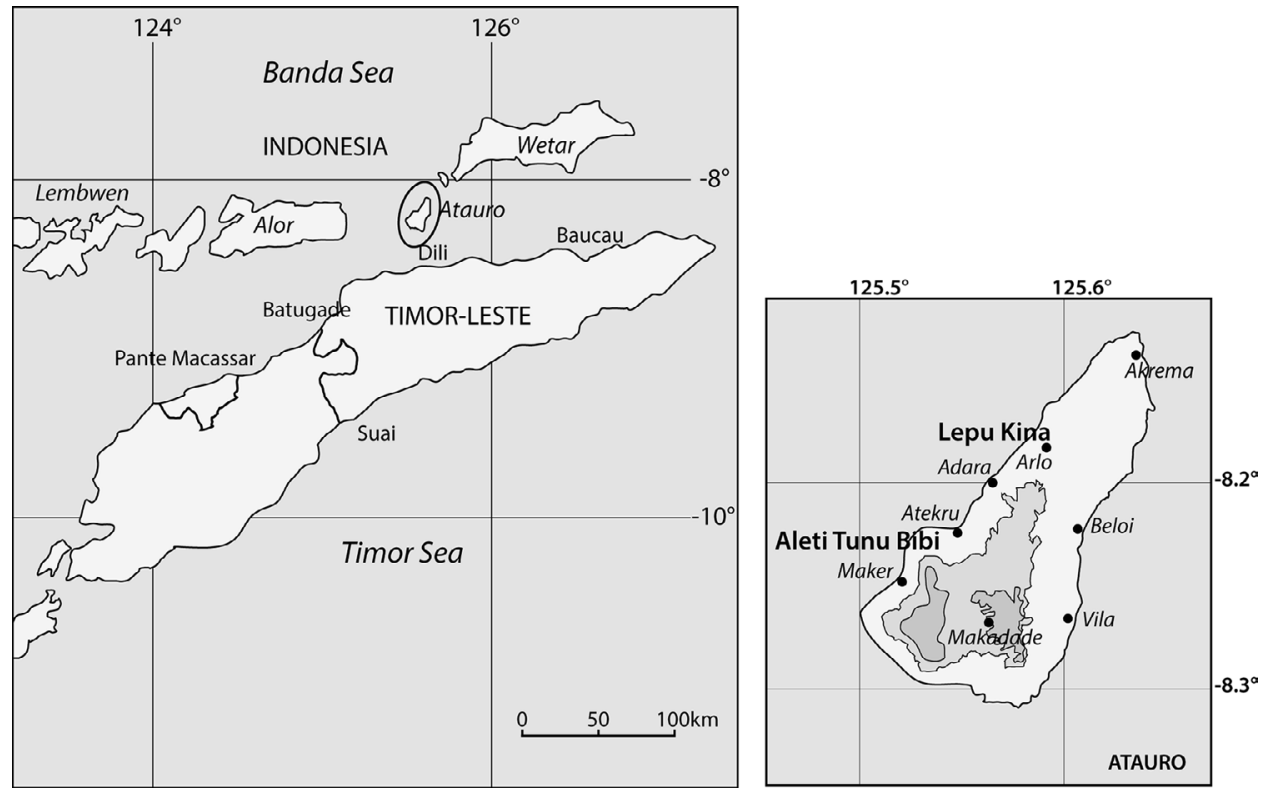

Fig. 1. Map of Timor and Atauro.

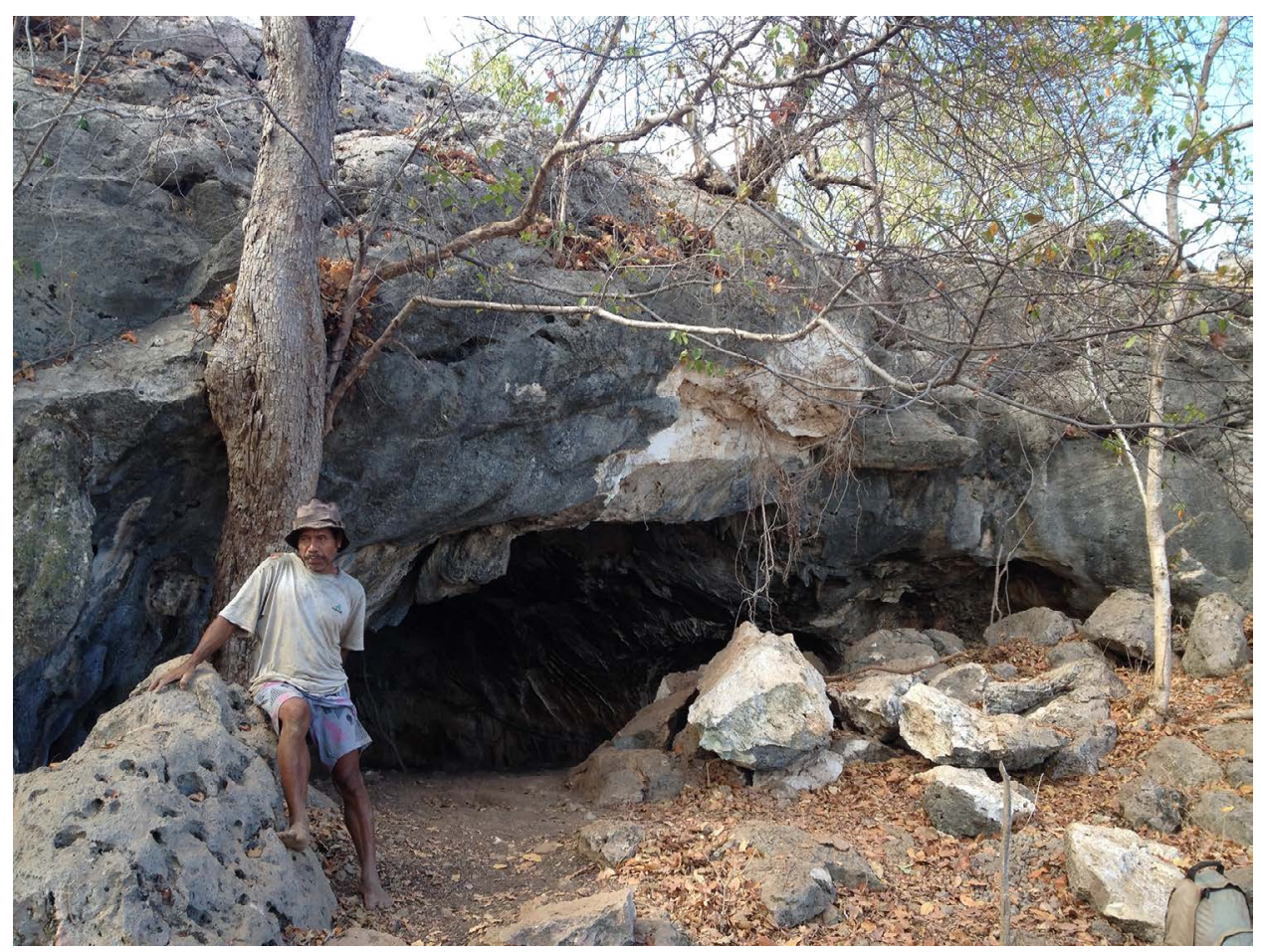

Fig. 2. Cornelius Soares in front of Aleti Tunu Bibi rock shelter in Atekru, Atauro. Photo by JeanChristophe Galipaud 2015. 


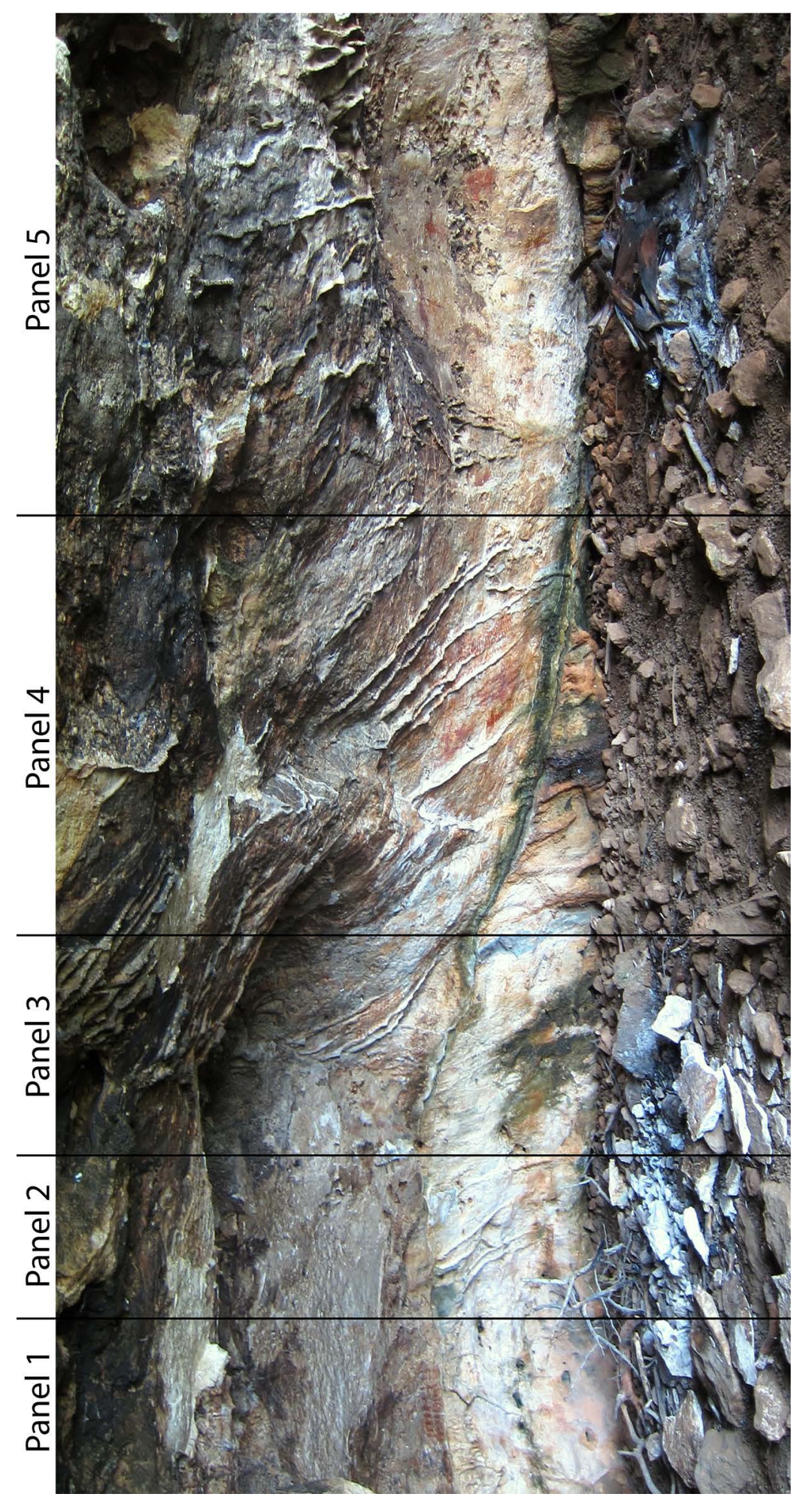

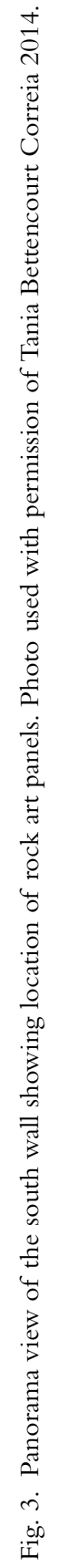




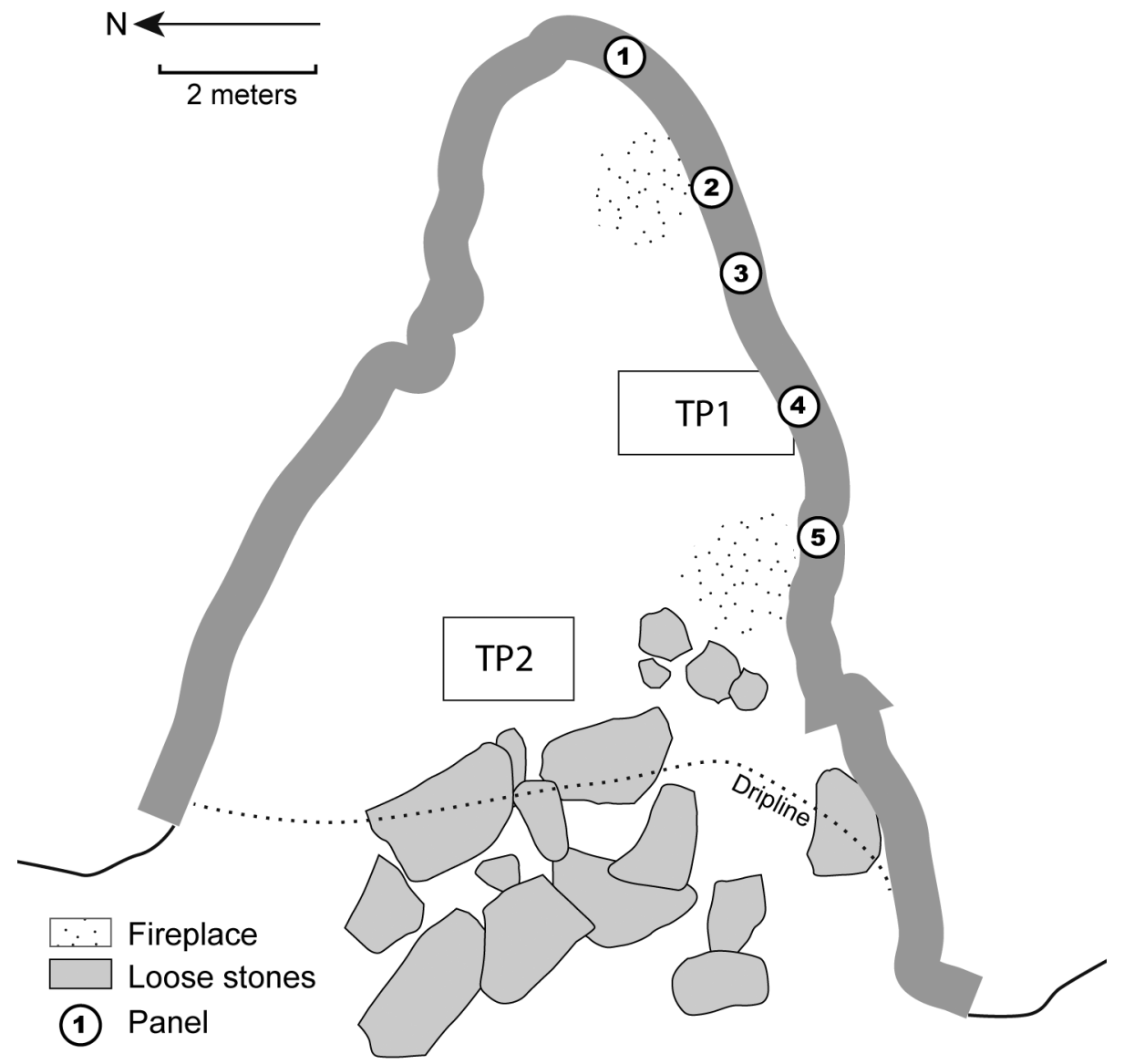

Fig. 4. Floor plan of Aleti Tunu Bibi rock shelter.

cave. All observable rock art was photographed and sheets of transparent plastic were positioned adjacent to the cave walls so the rock art could be directly traced on to this medium for more accurate interpretation of the designs. The photographs of the rock art were enhanced using Photoshop and the designs were extracted for a more complete rendering of the pictograms; some faint images were enhanced using the DStretch plugin of ImageJ software. ${ }^{3}$

Excavation to $0.7 \mathrm{~m}$ of an initial $50 \mathrm{~cm} \times 50 \mathrm{~cm}$ test pit at the entrance of the shelter in May 2015 identified a small amount of cultural material (described below). Two further $1.5 \mathrm{~m} \times 1.5 \mathrm{~m}$ squares were excavated three months later. Test pit 1 (TP1) was dug up to $0.7 \mathrm{~m}$ and Test pit 2 (TP2) reached $1.4 \mathrm{~m}$ (Fig. 4).

Dating of the Aleti Tunu Bibi archaeological contexts indicates an intermittent use of the shelter from as early as 18,000 years ago (Beta 419827) (Table 1). Relatively small amounts of pottery and stone artifacts were found in the deposits from Aleti Tunu Bibi compared to the Lepu Kina cave site. Stone artifacts including flaked and worked stone made from obsidian and chert were identified in deposits, including the 


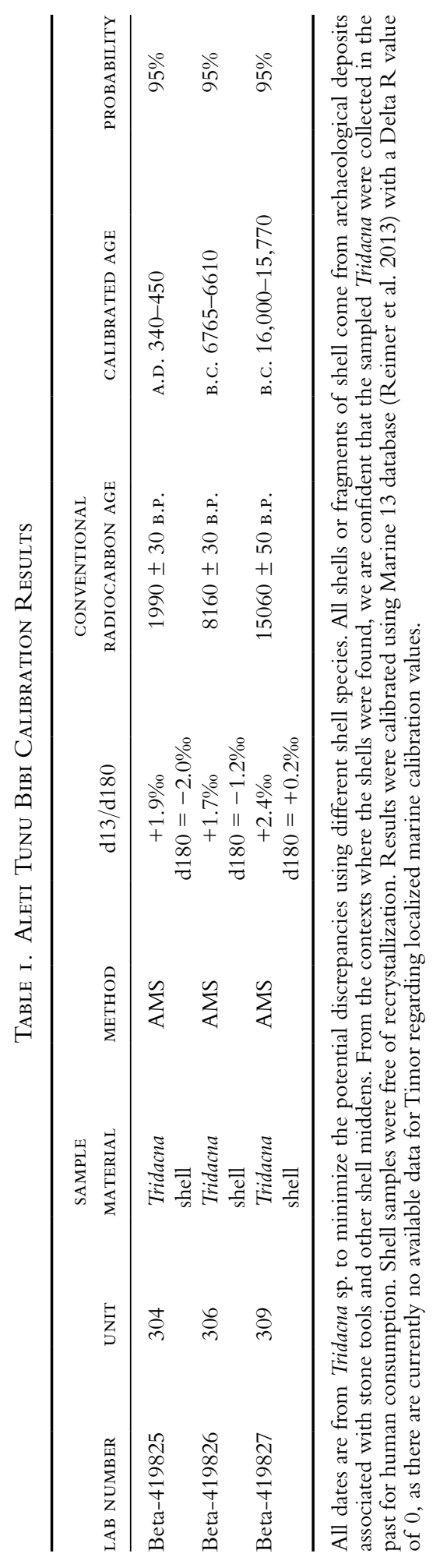


oldest layers. Obsidian flakes were particularly abundant in the Neolithic layers of another shelter on the island, Lepu Kina, but their occurrence in Pleistocene or early Holocene layers has been documented at other sites in Timor (Glover 1986; Reepmeyer et al. 2011). The recent analysis by Reepmeyer (pers. comm.) of samples of volcanic glass that were collected in the vicinity of Aleti Tunu Bibi suggests that Atauro, or one of the nearby islands, could be the source of obsidian found in many sites in the region.

At Aleti Tunu Bibi, hematite (red and yellow) was found in layers that also contained obsidian stone flakes and tools dated to at least 8500 years ago (Beta 419826 in Table 1). The hematite could only have arrived inside the cave through the action of humans, as there are no iron-rich rocks in the vicinity of the limestone cave. Precise dating of the rock art would need to incorporate absolute dating of overlaying calcite accretions or charcoal deposits. However, the fact that calcite accretions were found to have formed over some of the paintings within a one-year period or less from 2014 to 2015 may indicate that this type of dating is not appropriate for Aleti Tunu Bibi, or other rock art sites in the region for that matter (Fig. 5).

\section{ROCK ART AT ALETI TUNU BIBI}

A total of thirteen paintings in red, one painting in black, and one drawing in black have been recorded at Aleti Tunu Bibi (Figs. 6-11). Most of the pictograms were painted on relatively flat areas of the wall on a naturally white surface. Drawings were often difficult to discern due to the uneven nature of the walls. In some cases, calcite accretions and black mold further complicated interpretations of the designs. All but three of the designs were executed with monochrome red pigment, two designs were painted in black pigment, and one motif of a boat was drawn with dry charcoal. The red pigment was present in a range of colors from bright red to dark red-brown and, in one instance, purple-red. There was no evidence of superposition of motifs. The preservation was generally good, and the majority of the painted motifs are still very clear; however, a few motifs have been partly damaged where calcite layers have peeled away from the cave walls. Some reddish stains on calcite deposits suggest that some red paintings may have been fully covered by accretions, especially in the lower parts of the wall close to the cave floor. Further analysis of these calcite layers and possible pigment will need to be conducted to confirm this hypothesis.

At least five different motifs are represented in the designs:

1. The most frequent motif is a zoomorph lizard/crocodile figure with an oval-shaped body, legs, and tail (Figs. 8, 9);

2. A larger zoomorph may represent a sea mammal or fish (Fig. 10);

3. Parallel lines (Fig. 6);

4. Dots and short lines, some of which make use of natural calcite ribbons that have formed on the cave walls (Fig. 10);

5. A possible boat (Fig. 7).

There was no visible superimposition of pictograms, but some zoomorphic figures may have been repainted several times.

There were at least ten zoomorph paintings. One or perhaps two are partly hidden by calcite accretions in Panel 2 (black motifs in Fig. 8). Other zoomorphs appeared in groups of three in Panels 3 to 5 (red motifs in Figs. 9-11). Zoomorph figures were 

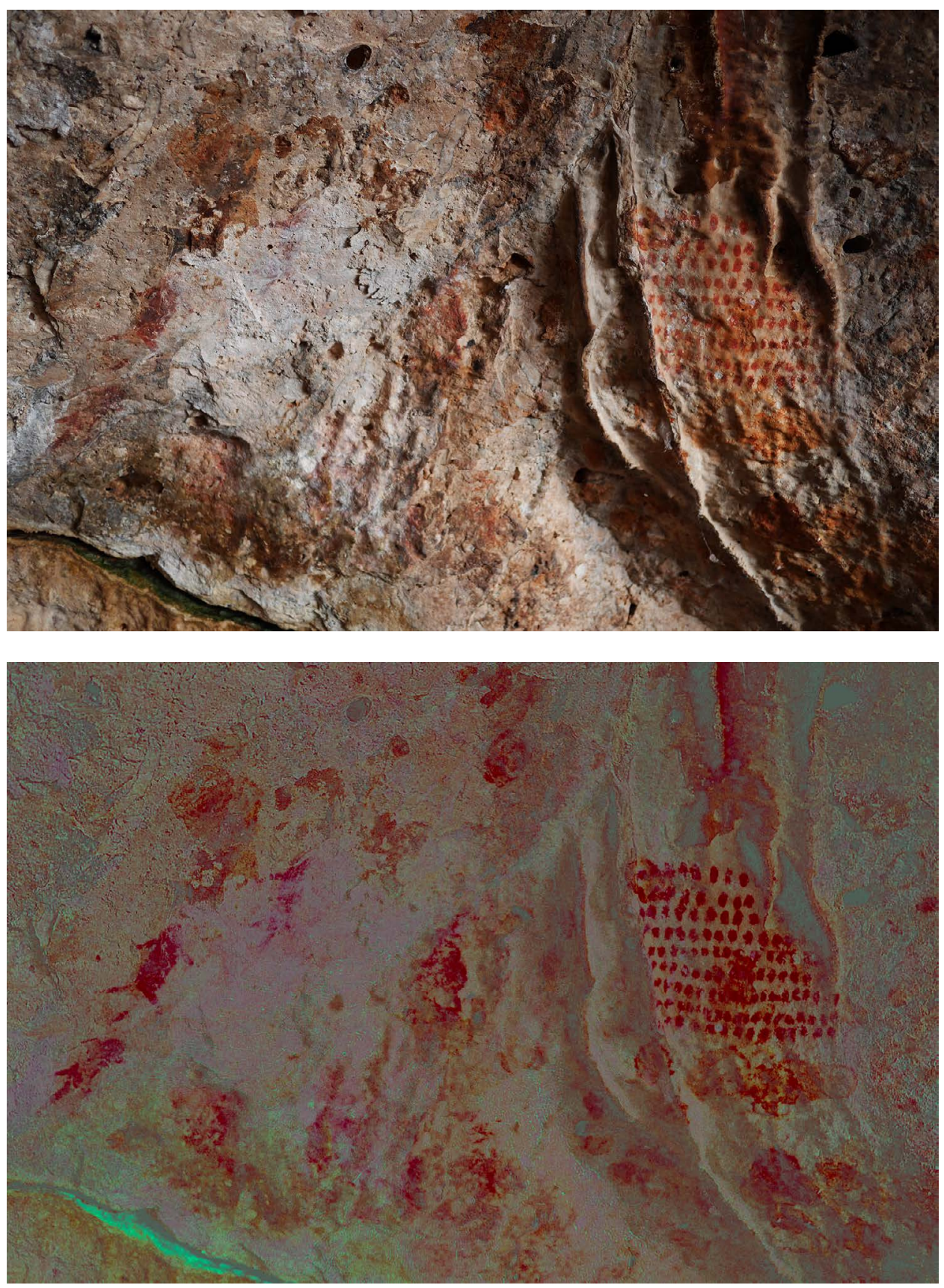

Fig. 5. Calcite veil formed in 2015 over rock paintings in Panel 3 (above); enhanced image using DStretch by Jon Harman, V.7.0, April 2010 (below). Photo by Jean-Christophe Galipaud 2015. 


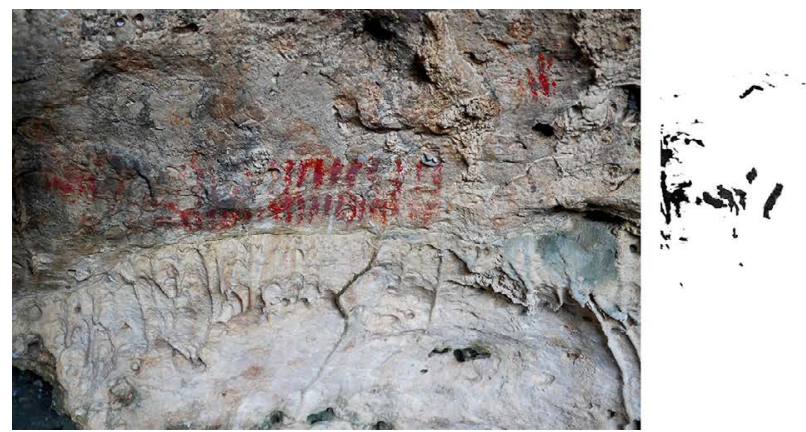

Fig. 6. Panel 1: rock art detail magnified and enhanced with Photoshop (left); design extracted from background (right). Photo by Jean-Christophe Galipaud 2015.
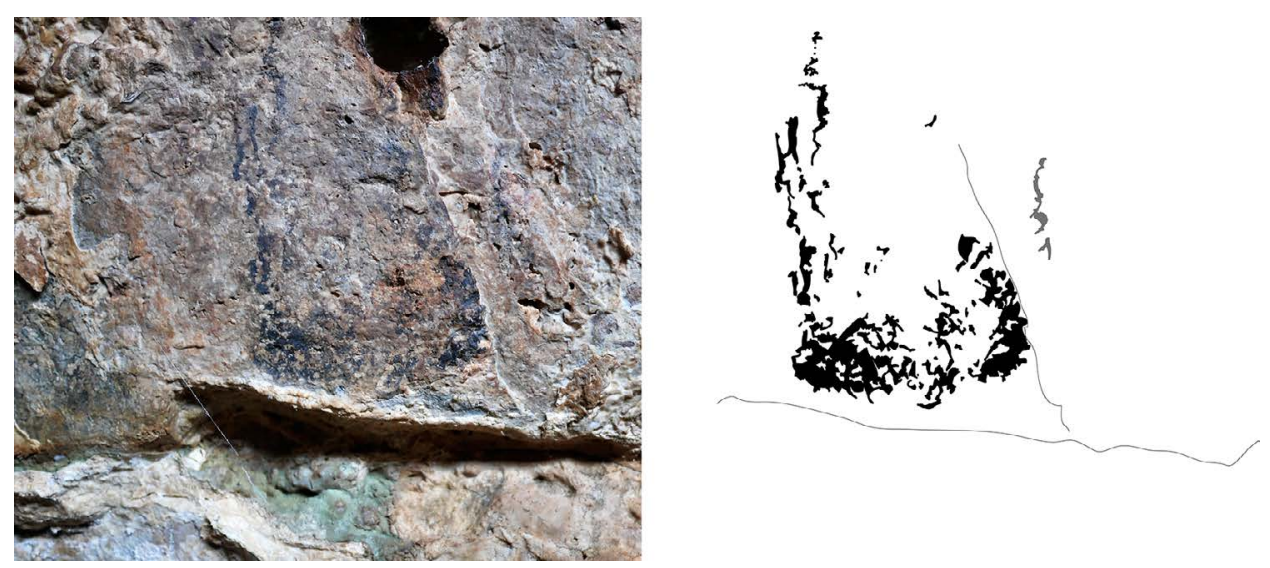

Fig. 7. Panel 2: Rock art detail possibly a charcoal drawing of a boat (left); design extracted from background (right). Photo by Jean-Christophe Galipaud 2015.

painted as thick elongated bodies with two to four appendices and, in some instances, a tail. It was difficult to determine whether the variation in the shapes of the zoomorphs was a result of the quality of the pictogram or if the differences represent unique designs.

Other motifs included linear parallel lines at the back of the cave (Panel 1) and rows of dots in red pigment (Panel 3). In Panel 3, a series of nine lines of dots comprising between nine and thirteen dots each filled a white, generally flat surface between two upraised calcareous ribbons (Fig. 5). The most elaborate set of motifs, located in Panel 4, is a seemingly organized panel associating three zoomorphic figures, linear motifs, and short lines or dots, some of which were closely associated with natural calcareous ribbons (Fig. 10). The artist has highlighted them with lines or dots. This elaborate combination seems to tell a story or depict a scene of a hunt. This panel is reminiscent of the whale hunt scene at the Bangudae rock art site in South Korea.

The Aleti Tunu Bibi cave fits more or less within the criteria proposed by Ballard (1992) for sites associated with the APT. Specifically, the cave is located on limestone terraces close to the current coastline, provides a direct view overlooking the sea, and 


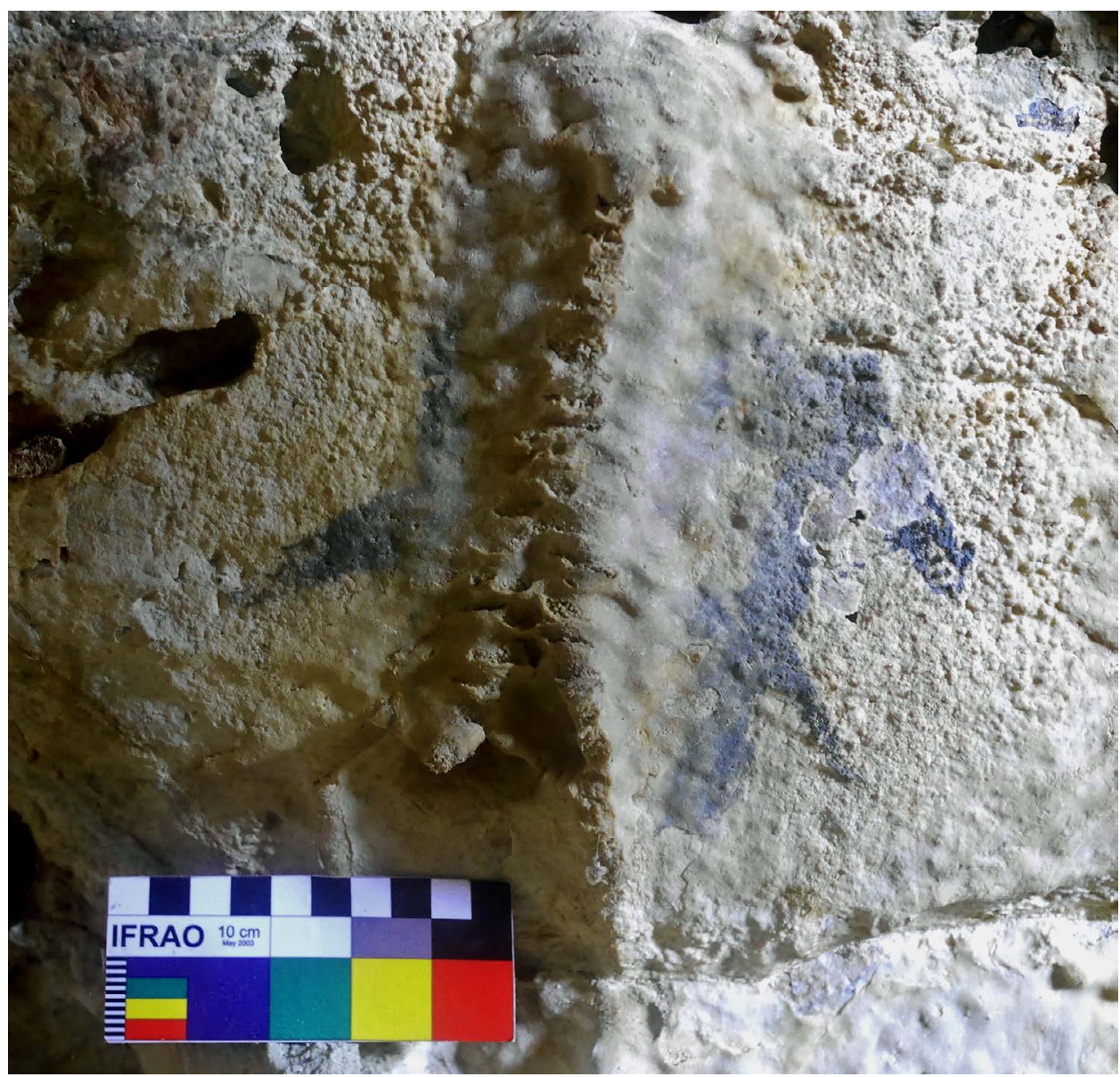

Fig. 8. Panel 2: detail of the only two black zoomorphs, partly covered by thick calcite ribbon. Photo by Jean-Christophe Galipaud 2015.

is in an area settled by Austronesian-speaking populations. However, as a result of its elevation, the mouth of the cave is not easily observable from the sea. This, and the fact that the rock art was painted well within the cave, means the art is not "highly visible," unlike other APT sites in the region. Aleti Tunu Bibi is one of the few caves in the area located near the sea. Other caves are set farther inland. Of the multiple caves and rock overhangs surveyed on the west coast of Atauro, this site is the only one so far to contain observable rock art. Although Austronesian-speaking populations live on Atauro today, we are cautious to associate the modern-day language distribution directly with the linguistic situation during the Neolithic/Early Metal Age, especially in an area of ISEA that has a complex settlement history. In this region, languages are known to reflect both Austronesian and non-Austronesian influences (Schapper 2015; McWilliam 2007).

On stylistic grounds, Aleti Tunu Bibi cannot readily be associated with the Austronesian Painting Tradition (O'Connor 2003; Tan 2014; Wilson 2002). Some 


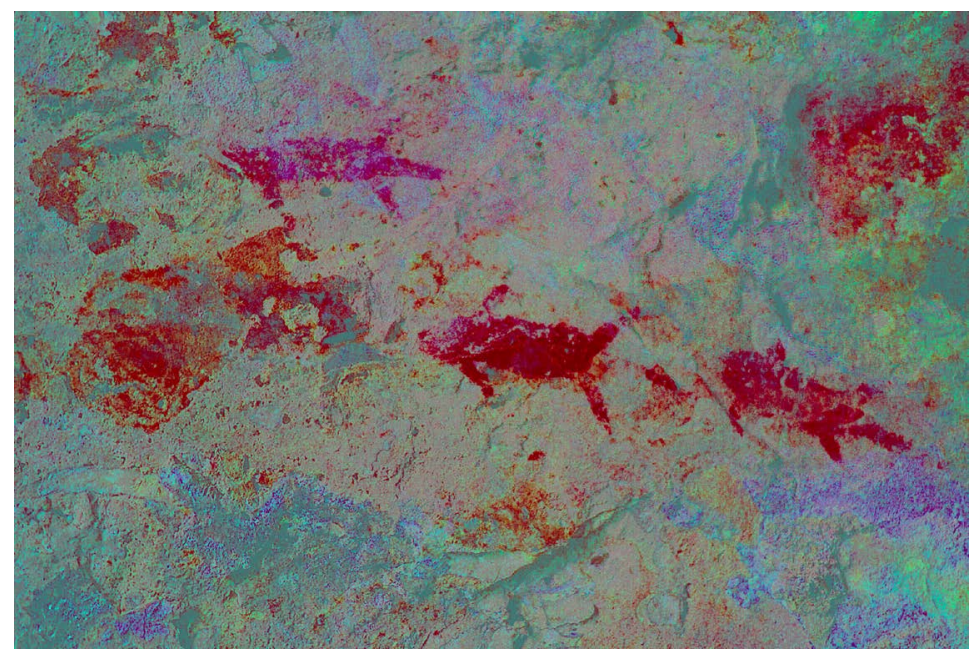

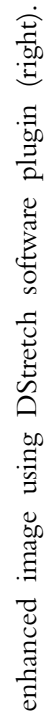
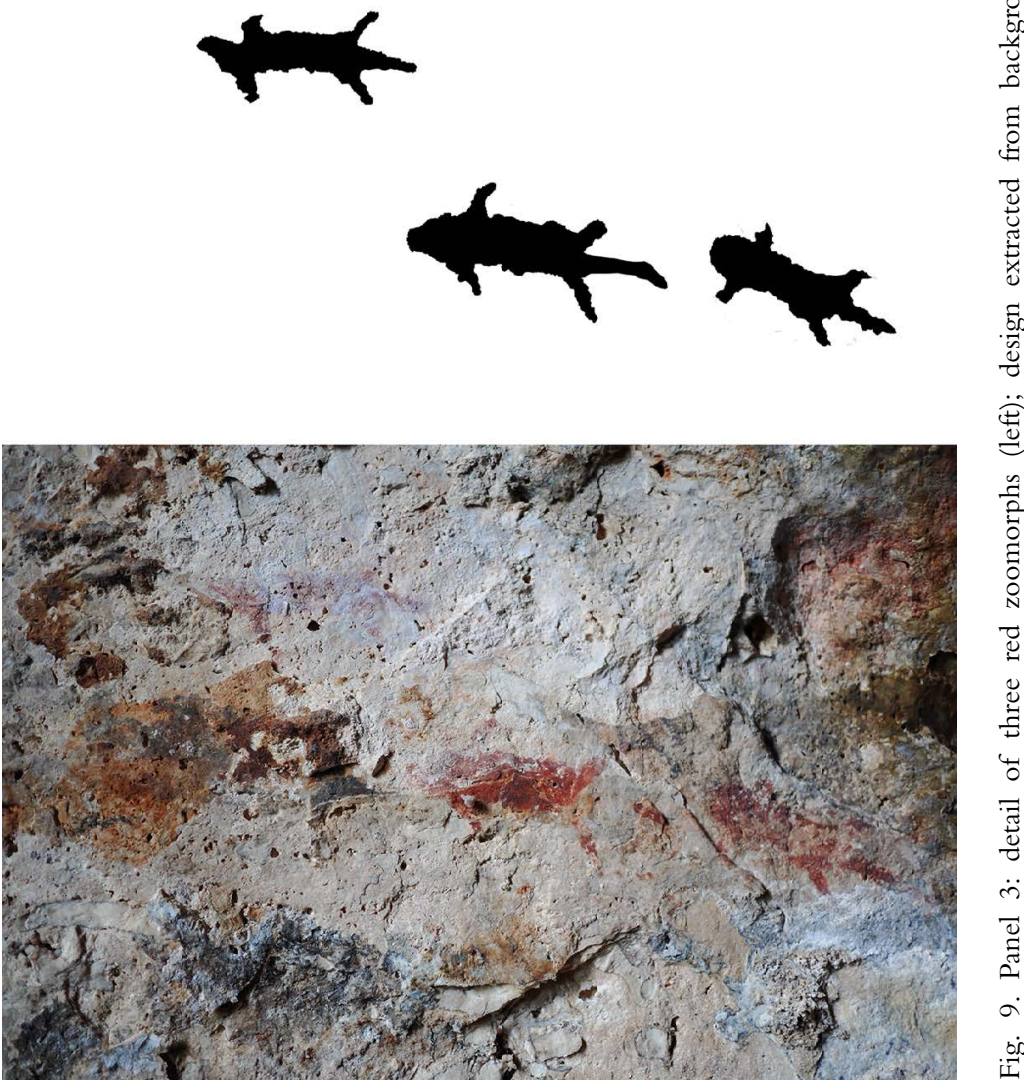

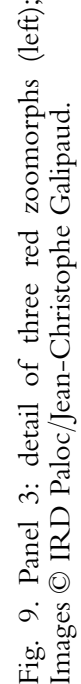



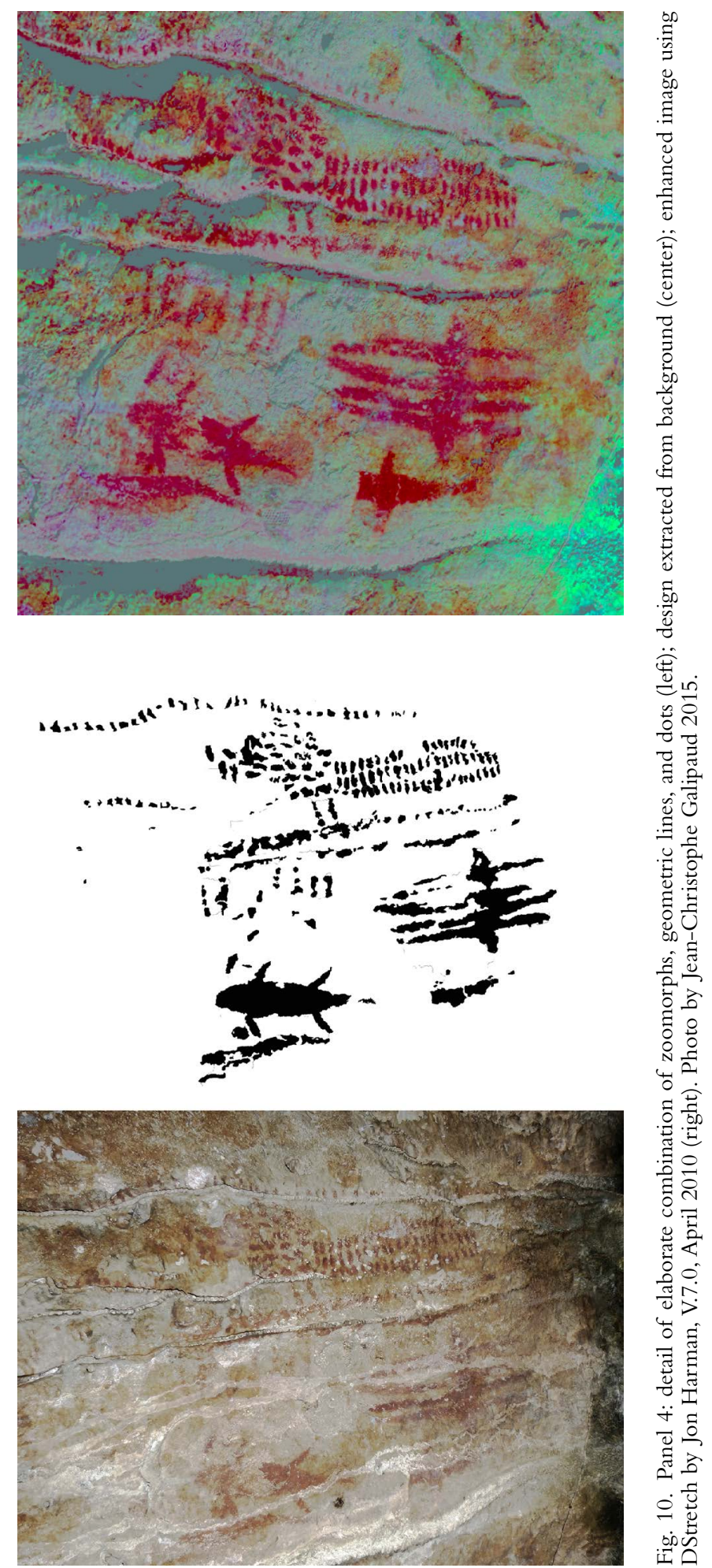

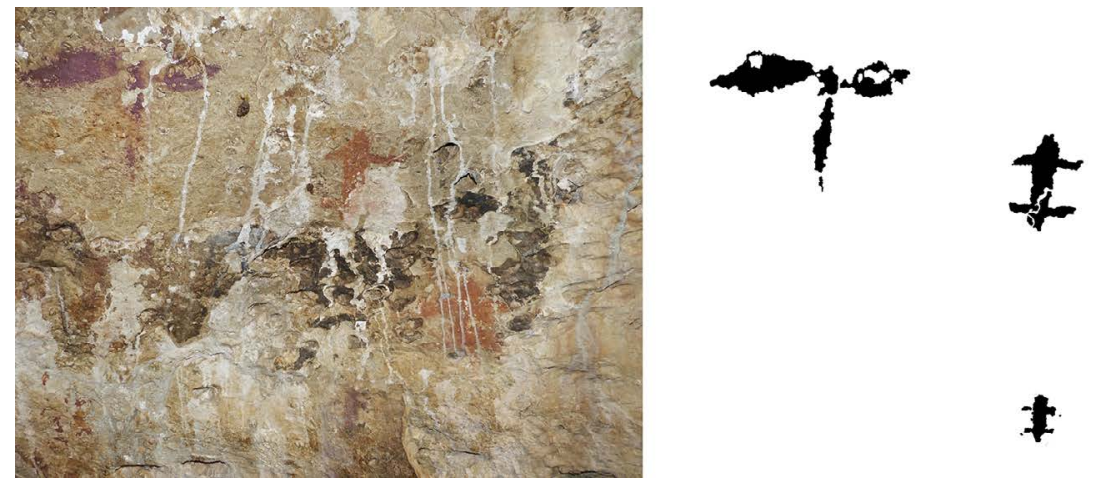

Fig. 11. Panel 5: detail of zoomorphs, possibly a group of turtles (left); extracted design (right). Photo by Jean-Christophe Galipaud 2015.

characteristics of the Aleti Tunu Bibi rock art are more similar to other sites in East Timor, namely some motif types, presence of pictograms deeper in caves, and use of red and black pigments (O'Connor 2003; O'Connor and Oliveira 2007). The primary motifs found at Aleti Tunu Bibi are zoomorphs (identified as likely lizard/crocodiles and perhaps fish/sea mammals) and lines and dots/lines that may be associated with counting. Similar zoomorphs have been found at a number of rock art sites in East Timor, but the simplicity of the designs at Aleti Tunu Bibi distinguish it from these other sites. Furthermore, none of the zoomorphs at Aleti Tunu Bibi appear to be anthropomorphic. The pictograms in Aleti Tunu Bibi, which are uniquely made using the wet paint technique, do not show any details of hands or feet, unlike anthropomorphic pictograms found in sites on the north and east coasts of East Timor.

We are aware of only very few comparable zoomorph designs on the nearby island of Alor, in the Tron Bon Lei cave (O'Connor pers. com.) and, to a lesser extent, in the Lia Doku Lia Doka shelter in Baucau (Guillaud et al. 2007; Guillaud and Galipaud 2012) (Fig. 12). In the region, zoomorph and anthropomorph figures are generally considered to be later in time than hand stencils (Chazine et al. 2005; Wilson 2002), but in a few instances (including some from East Timor) hand stencils may be contemporary with other APT motifs (O'Connor 2003). None of the human, horse, spiral, and sun motifs or hand stencils found at other East Timor sites were identified at Aleti Tunu Bibi (Fig. 13).

The painted dots and lines at the site may be representative of an early counting system, though for what exact purpose remains unknown. Painted dots are also present in at least one rock art site in Timor in Lie Gere (Fig. 14), and parallel lines in red pigment have been observed in Hatu Wakik, a shelter in the Manatuto area (Forestier and Guillaud 2013) (Fig. 15).

Given the lack of figurative anthropomorphs and geometrically complex figures, the rock art at Aleti Tunu Bibi does not seem similar enough to other sites described in East Timor to be associated with what O'Connor and Oliveira (2007: 400) describe as "a central interactive cultural sphere that stretched from the north coast and into the mountainous spine of East Timor about 2000 years ago." The rock art at Aleti Tunu Bibi more closely resembles what O'Connor describes as "a distinct group of motifs in deep accessible locations [that] includes hand stencils, geometrics, and sim- 


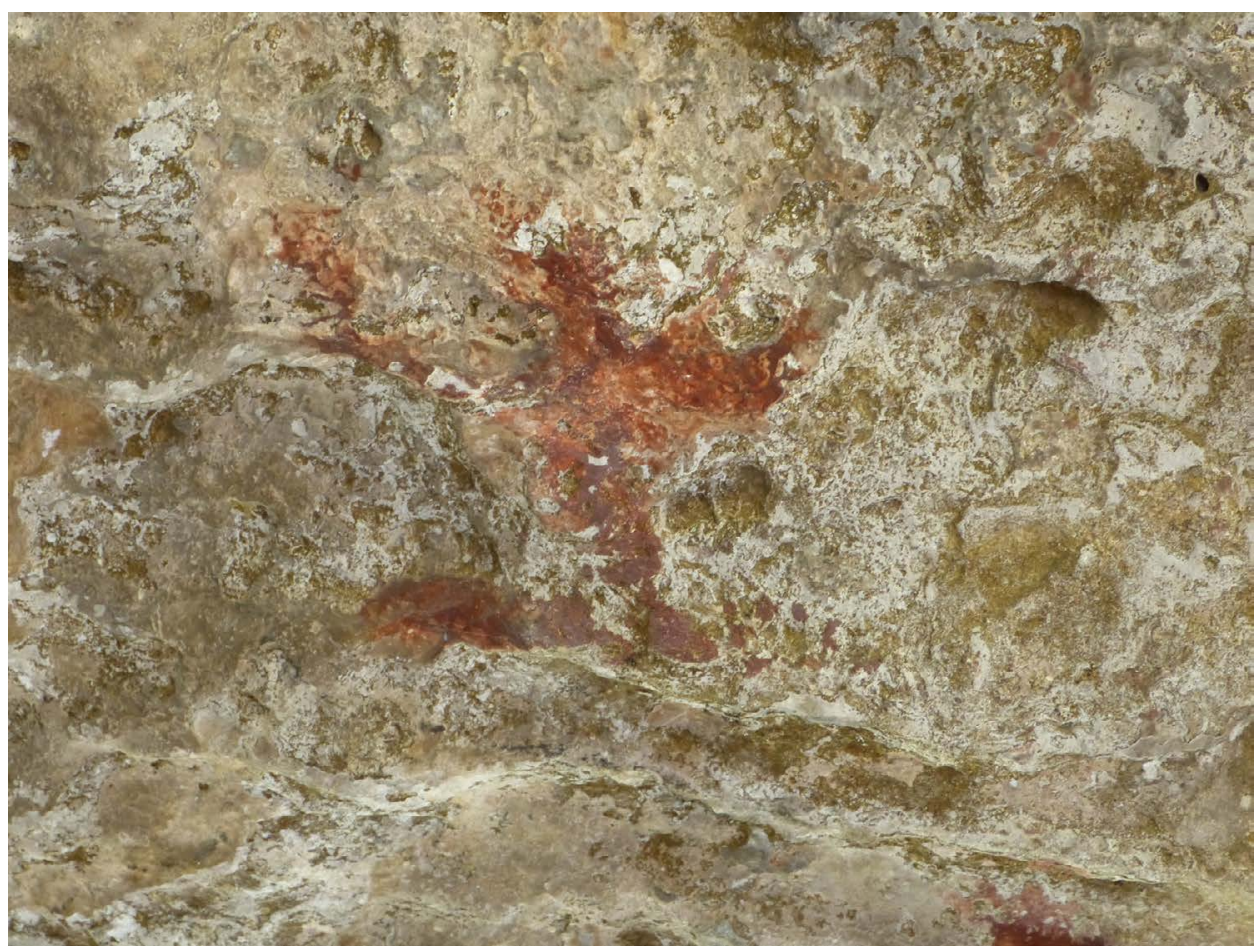

Fig. 12. Red zoomorph painted on Lia Doku Lia Doka, Baucau. Photo by Jean-Christophe Galipaud 2015.

ple red figurative motifs." O'Connor distinguishes this group from others based on distribution, but notes that "there is no evidence that this grouping is separated chronologically from the art on the exposed sea-cliff panels-it may simply have served a different function" (2003:124).

Paintings located deeper in caves, but in relatively accessible locations, have been found at other rock art sites in both central and eastern East Timor. The diversity in motif styles between the two areas is thought to represent separate stylistic regions (O'Connor and Oliveira 2007). There is limited variation in the motifs and a general similarity in designs of the rock art from Aleti Tunu Bibi compared with the diversity and relative complexity of rock art from these other areas.

The limited variety of paintings, the absence of superimposition of the designs, and the organization of Panels 3 or 4, for example, suggest that the rock art in Aleti Tunu Bibi was painted in a limited time frame. At least one of the two black pictograms - the drawing of a boat - could represent a later temporal event, however (Fig. 7). Boat designs are a common feature of the artistic tradition of the region. Ship symbolism appears in Borneo, southern Sulawesi, eastern Indonesia, East Timor, and western New Guinea (Ballard et al. 2003). The depiction of boats in rock art and on artifacts such as Dongson drums have been associated with the "ship of the dead" cosmology of the Late Neolithic and Early Metal Age in the region (c. 2000 B.P.) (Ballard 1992; Ballard et al. 2003; Harrison 1958; Spennemann 1985; Szabo et al. 2000). ${ }^{4}$ Boat-shaped coffins throughout the region, including some in contexts 


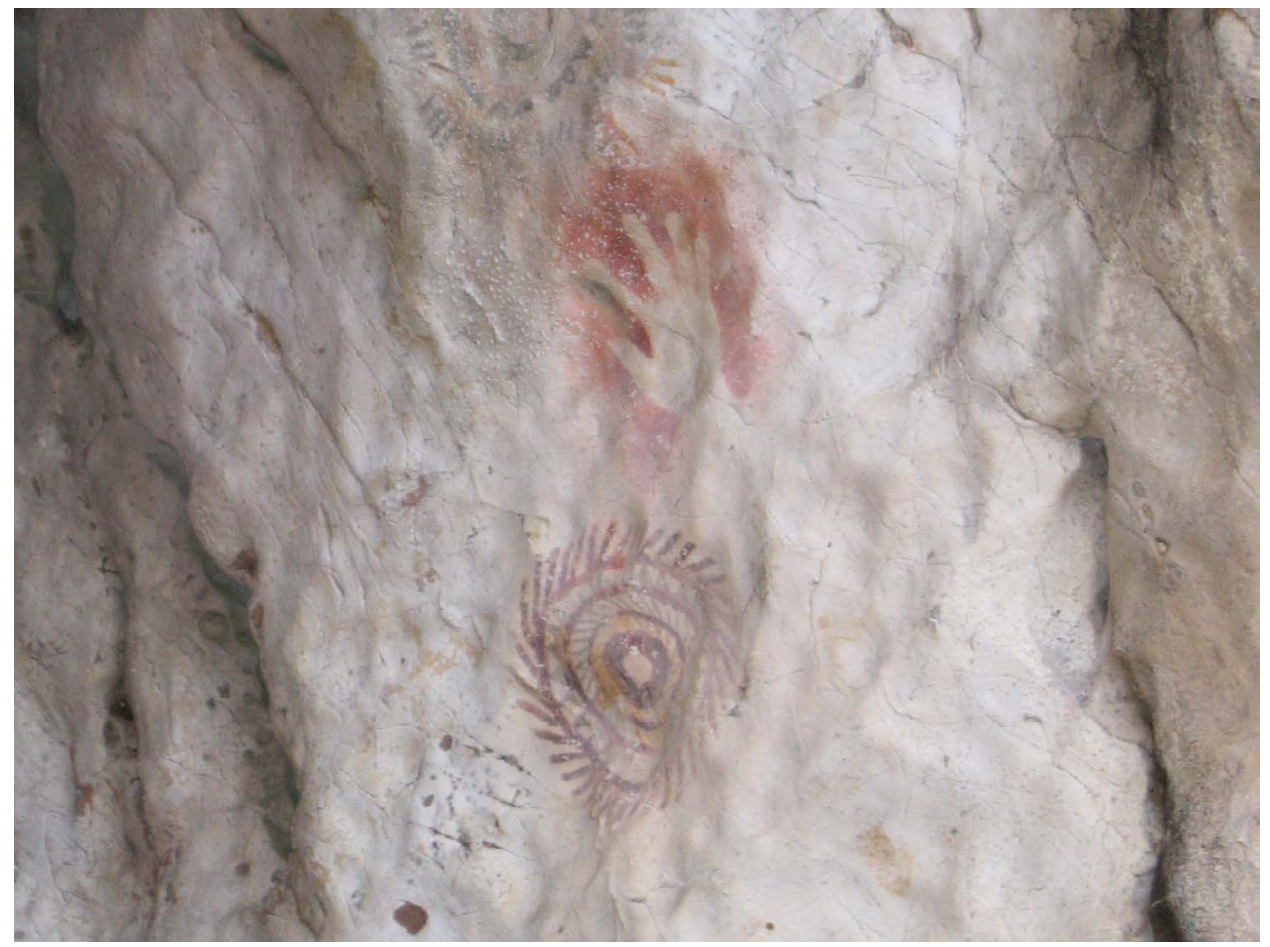

Fig. 13. Hand stencil in Ili Kere cave, East Timor. Photograph used with permission of David Palazon.

associated with boat rock art, have also been linked with the "ship of the dead," a means of transporting the soul of the deceased to its next destination (Ballard 1992; Röder 1956; Szabo et al. 2000). Ballard and colleagues (2003) propose that rock art (including boat motifs) and mortuary rituals are intrinsically associated in Island Southeast Asia (including the Philippines, the Indonesian and Malaysian parts of Borneo, and eastern Indonesia), and in the western Pacific at least as far east as the Solomon Islands. Throughout these regions, boat "art symbolizes widely shared beliefs and activities associated with death" (Ballard et al. 2003:394). The lack of evidence for domestic use of Aleti Tunu Bibi, coupled with the fact that unarticulated human bones were found in the archaeological contexts of the site, supports the suggestion that the cave was primarily used as a sacred space, likely for mortuary rituals. Interestingly, today the cave is also known as a sacred location. The name of the cave roughly translates to "the place where goats are roasted to chase away demons." While goats are a recent introduction to Timor, the presence of rock art and human remains suggests the cave may have been associated with sacred rituals since ancient times.

The occurrence of red and yellow ochre in the excavated trenches in layers dated to around 8000 B.P. is a potential indication of the use of these pigments during the early Holocene. While it is difficult at this stage to draw a clear line between this evidence and the appearance of rock art on the walls of the cave, it is possible that the red paintings at Aleti Tunu Bibi were drawn during this period. Red ochre in Pleistocene or early Holocene archaeological deposits is not uncommon in Timor. In Bui 


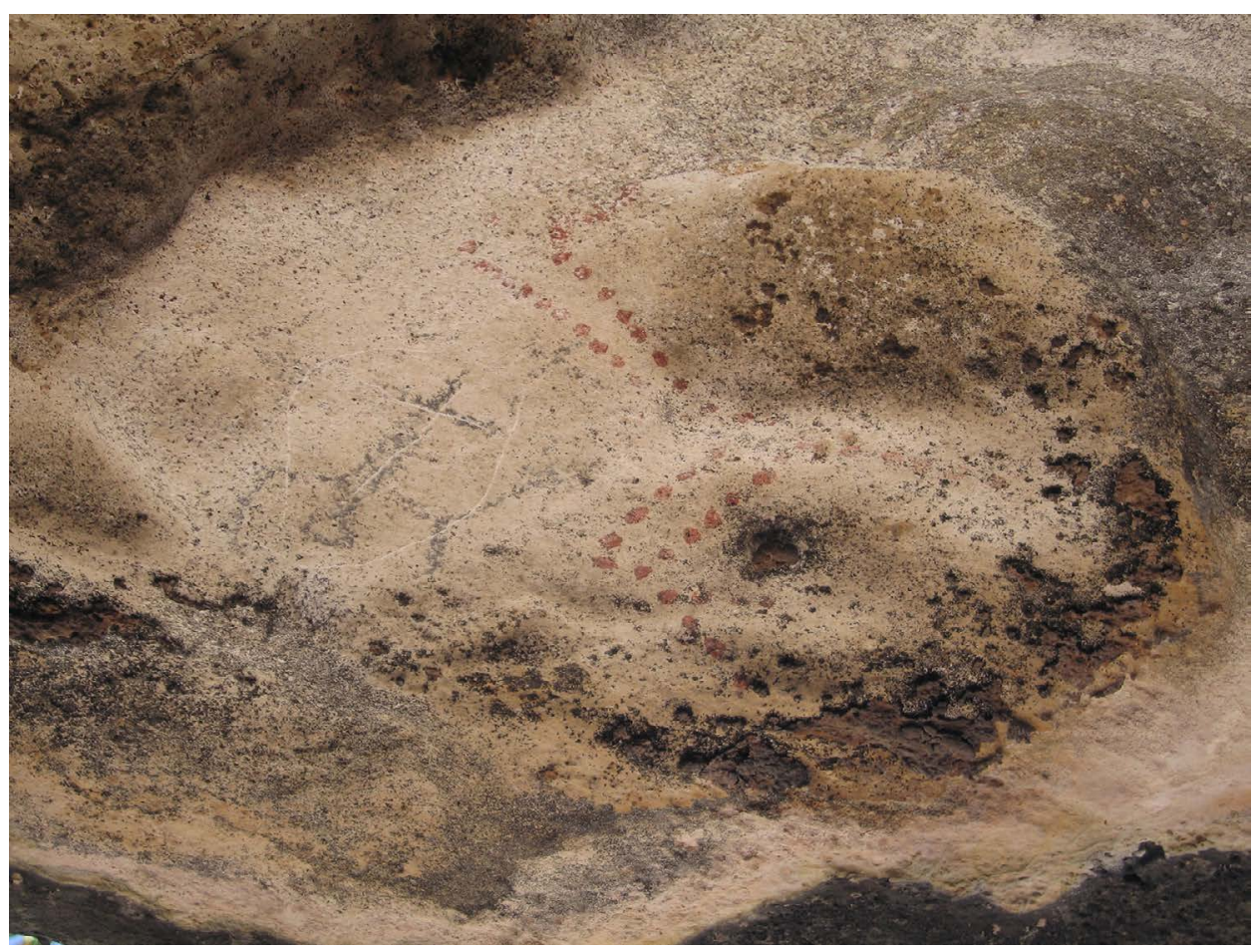

Fig. 14. Red painted dots in the Lie Gere rock shelter, East Timor. Photograph used with permission of David Palazon.

Ceri Uato (Glover 1986:112), ochre was present in Layers II to V dated to between 4500 and 7500 B.P. In Lie Siri, red ochre was present in nearly all layers and could have been used for the manufacture of pigments "perhaps to make the hand stencils at the back of the cave" (Glover 1986:75). Pellets of red ochre were also present in Lene Hara cave in a Pleistocene context (Aubert et al. 2007:995). It is therefore possible that simpler figurative motifs, geometric designs, and sometimes (but not in Atekru so far) hand stencils are associated with a chronologically older rock painting tradition in Timor.

\section{CONCLUSIONS}

Aubert and colleagues (2007: 991) state that "rock art has the unique potential to inform on symbolic expressions and cultural practices, and therefore provides one of the few 'windows' into the way people thought in non-literate societies." The Aleti Tunu Bibi rock art site provides the first evidence for rock art on the island of Atauro and extends the known distribution of rock art sites in East Timor across the Wetar Strait. The dating of the site suggests limited use of the shelter from as early as 18,000 B.P. and up into the Neolithic.

The simple figurative zoomorph motifs and linear or dotted designs found in the shelter may represent an older rock art tradition in the region. The boat drawn in black pigment could post-date these red paintings. The boat may be associated with 


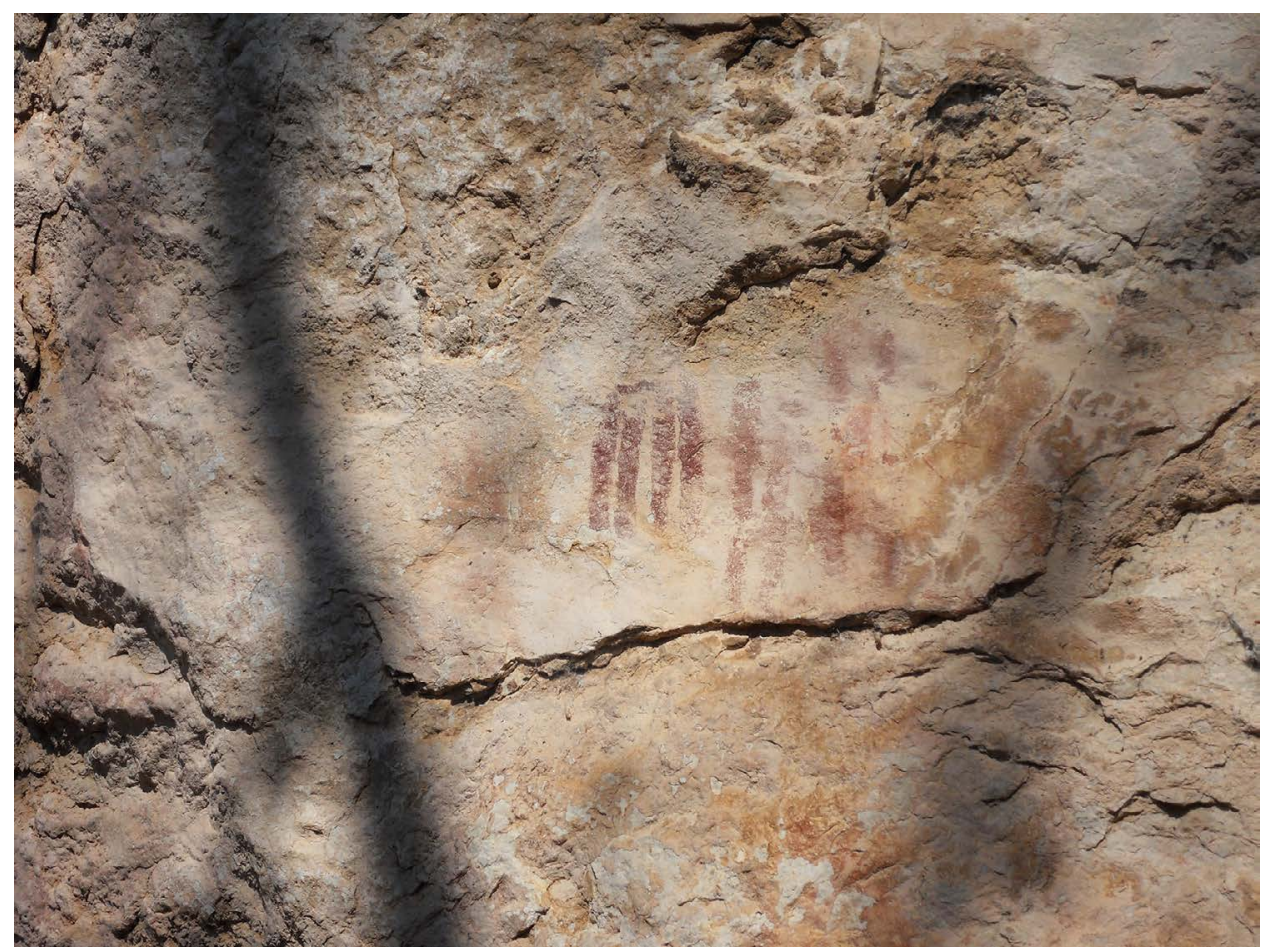

Fig. 15. Red parallel lines in Hatu Wakik, Manatuto. Photo by Jean-Christophe Galipaud 2015.

the "ship of the dead" cosmology that is represented during the Early Metal Age on Dongson drums traded throughout the region. This suggests that the dry black drawing of the boat dates to not earlier than 2000 B.P.

The Aleti Tunu Bibi site shares a number of attributes with other rock art sites in the region and East Timor, providing evidence for regional connections and a shared belief system before and during the Neolithic and Early Metal Age. However, the simplicity of designs and the focus on specific red-painted motifs combined with dots and lines distinguishes Aleti Tunu Bibi from the most eastern Timorese sites and hints at specific older connections with the mainland around Baucau as well as islands farther north and west, possibly as far as South Korea, in environments associated with sea hunting.

The lack of evidence for a domestic use of the cave, the presence of human remains in the archeological context, and the occurrence of the rock art possibly indicate that the site was used as a sacred space for a long period of time. Future analyses should incorporate dating of the charcoal rock art and, possibly, the calcite accretions overlying the rock art, although the fast deposition of some of these accretions $(<1$ year) may indicate that this type of dating is not appropriate for the site.

\section{ACKNOWLEDGMENTS}

The research in Atekru was conducted with a grant from IFI (Institut Français d'Indonésie) in cooperation with the State Secretariat for Art and Culture of the Ministry of Tourism of Timor-Leste. We would like to thank our colleagues from the SSAC 
archaeology unit in Dili, the chiefs and people of the villages of Arlo, Adara, and Atekru in Atauro, as well as Barry in Beloi, Atauro and Tania Bettencourt in Dili and Atauro for their support in setting up and conducting this mission as well as two anonymous reviewers for their very useful comments and suggestions.

\section{NOTES}

1. See O'Connor 2003 and Wilson 2004 for comprehensive discussions of the debates surrounding APT for the region.

2. See Specht 1979 and Rosenfeld 1988 for earlier studies.

3. ImageJ Ver. 1.49, Wayne Rasband, National Institute of Health, USA, http://imagej.nih.gov; DStretch plugin by Jon Harman Ver. 7.0, April 2010, www.DStretch.com.

4. The first complete example of a Dongson drum in the region was recently found in Baucau, East Timor (Oliveira 2015).

\section{REFERENCES CITED}

Aubert, Maxime, A. Brumm, M. Ramli, T. Sutikna, E. W. Saptomo, B. Hakim, M. J. Morwood, G. D. van den Bergh, L. Kinsley, and A. Dosetto

2014 Pleistocene cave art from Sulawesi, Indonesia. Nature 514(7521): 223-227.

Aubert, Maxime, Sue O’Connor, Malcolm McCulloch, Graham Mortimer, Alan Watchman, AND MARC Richer-LAFlèche

2007 Uranium-series dating rock art in East Timor. Journal of Archaeological Science 34(6) : 991-996.

Ballard, Chris

1992 Painted rock art sites in Western Melanesia: Locational evidence for an "Austronesian" tradition, in State of the Art: Regional Art Studies in Australia and Melanesia: 94-105, ed. J. McDonald and I. P. Haskovec. Occasional AURA Papers 4. Melbourne: Australian Rock Art Research Association.

Ballard, Chris, L. Nordenborg Myhre, and M.R.B. Wilson

2003 The ship as symbol in the prehistory of Scandinavia and Southeast Asia. World Archaeology 35(3): 385-403.

Bulbeck, David

2004 Divided in space, united in time: The Holocene prehistory of South Sulawesi. Modern Quaternary Research in Southeast Asia 18:129-166.

Chappell, John, and H. H. Veeh

1978 Late Quaternary tectonic movements and sea-level changes at Timor and Atauro Island. Geological Society of America Bulletin 89(3):356-368.

Chazine, Jean-Michel

2005 Rock art, burials, and habitations: Caves in East Kalimantan. Asian Perspectives 44(1):219230 .

Ely, Kim S., Mike Sandiford, Margaret Hawke, David Phillips, Mark Cameron Quigley, AND JoAo Edmundo doE Reis

2011 Evolution of Ataúro Island: Temporal constraints on subduction processes beneath the Wetar zone, Banda Arc. Journal of Asian Earth Sciences 41(6): 477-493.

Forestier, Hubert, ANd Dominique Guillaud

2013 A limestone outcrop as a landmark of prehistoric settlement in the Manatuto Region (East Timor), in Unearthing Southeast Asia's Past: Selected Papers from the 12th International Conference of the European Association of Southeast Asian Archaeologists, vol. 1:26-33, ed. M. J. Klokke and V. Degroot. Singapore: NUS Press.

GLOVER, IAN

1986 Archaeology in Eastern Timor, 1966-67. Canberra: Australian National University.

Guillaud, Dominique, Dorothée Dussy, and Hubert Forestier

2007 Rapport de mission exploratoire à Timor-Leste dans le domaine archéologique et ethnogéographique [Report of an archaeology and ethnogeography exploratory survey in East Timor]. Paris: Ms. IRD [Research Institute for Development]-CNRS-Ambassade de France. 
Guillaud, Dominique, and Jean-Christophe Galipaud

2012 Identities, territories and agricultural practices: Some landmarks for the preservation of local communities' heritage in East Timor. Preliminary report of a survey of East Timor in the field of Archaeology and Geography, September-October 2012. Paris: Ms. IRD [Research Institute for Development] and IFI [French Institute in Indonesia].

HARRISON, TOM

1958 The great cave, Sarawak: A ship-of-the-dead cult and related rock paintings. Archaeological News Letter 6(9): 199-203.

McWilliam, ANDrew

2007 Austronesian in linguistic disguise: Fataluku cultural fusion in East Timor. Journal of Southeast Asian Studies 38(2):355-375.

O’CONnOr, Sue

2003 Nine new painted rock art sites from East Timor in the context of the Western Pacific Region. Asian Perspectives 42(1): 96-128.

O’Connor, Sue, Ken Aplin, Emma Saint Pierre, and Yue-Xing Feng

2010 Faces of the ancestors revealed: Discovery and dating of a Pleistocene-age petroglyph in Lene Hara Cave, East Timor. Antiquity 84:649-665.

O’Connor, Sue, and Nuno V. Oliveira

2007 Inter- and intraregional variation in the Austronesian painting tradition: A view from East Timor. Asian Perspectives 46(2):389-403.

Oliveira, Nuno V.

2015 New reported bronze drums from Timor-Leste. Unpublished paper presented at the 15th International Conference of the European Association of Southeast Asian Archaeologists, Paris, France, 6-10 July 2015.

Plagnes, Valérie, Christianne Causse, Michel Fontugne, and Luc-Henri Fage

2003 Cross-dating (Th/U-14C) of calcite covering prehistoric paintings in Borneo. Quaternary Research 60:172-179.

Reepmeyer, Christian, Sue O’Connor, and Sally Brockwell

2011 Long-term obsidian use at the Jerimalai rock shelter in East Timor. Archaeology in Oceania 46:85-90.

Reimer, Paula J., Edouard Bard, Alex Bayliss, J. Warren Beck, Paul G. Blackwell, Christopher Bronk Ramsey, Caitlin E. Buck, Hai Cheng, R. Lawrence Edwards, Michael Friedrich, Pieter M. Grootes, Thomas P. Guilderson, Haflidi Haflidason, Irka Hajdas, Christine Hatté, Timothy J. Heaton, Dirk L. Hoffmann, Alan G. Hogg, Konrad A. Hughen, K. Felix Kaiser, Bernd Kromer, Sturt W. Manning, Mu Niu, Ron W. Reimer, David A. Richards, E. Marian Scott, John R. Southon, Richard A. Staff, Christian S. M. Turney, and Johannes van der PLICHT

2013 IntCal13 and Marine13 radiocarbon age calibration curves 0-50,000 years cal B.P. Radiocarbon 55(4) : 1869-1887.

RÖDER, JOSEF

1956 The rock paintings of the MacCluer Bay. Antiquity and Survival 1:387-400.

ROSENFELD, A.

1988 Rock art in western Oceania. Bulletin of the Indo-Pacific Prehistory Association 8:119-138.

SCHAPPER, ANTOINETTE

2015 Wallacea, a linguistic area. Archipel (90): 99-152.

Specht, Jim R.

1979 Rock art in the western Pacific, in Exploring the Visual Art of Oceania: Australia, Melanesia, Micronesia and Polynesia: 58-82, ed. S. M. Mead. Honolulu: University of Hawai'i Press.

Spennemann, Dirk H. R.

1985 On the Bronze Age ship model from Flores, Indonesia. The International Journal of Nautical Archaeology and Underwater Exploration 14(3): 237-241.

Szabó, Katherine, Philip J. Piper, and Graeme Barker

2000 Sailing between worlds: The symbolism of death in northwest Borneo, in Islands of Inquiry: 149-170, ed. G. Clark, F. Lech, and Sue O'Connor. Terra Australis 29. Canberra: ANU E-Press. 
Taçon Paul S. C., Noel Hidalgo Tan, Sue O’Connor, Ji Xueping, Li Gang, Darren Curnoe, David Bulbeck, Budianto Hakim, Iwan Sumantri, Heng Than, Im Sokrithy, Stephen Chia, Khuon Khun-Neay, and Soeung Kong

2014 The global implications of the early surviving rock art of greater Southeast Asia. Antiquity $88: 1050-1064$.

Tan, Noel Hidalgo

2014 Rock art research in Southeast Asia: A synthesis. Arts 3: 73-104.

\title{
WiLSON, MEREDITH
}

2002 Picturing Pacific Prehistory: The Rock-art of Vanuatu in a Western Pacific Context. Ph.D. thesis. Australian National University, Canberra.

2004 Rethinking regional analyses of western Pacific rock-art. Records of the Australian Museum Supplement 29:173-186.

Wilson, Meredith, Matthew Spriggs, and E. Lawsom

2001 Dating the rock art of Vanuatu: AMS radiocarbon determinations from abandoned mud-wasp nests and charcoal pigment found in superimposition. Rock Art Research 18:24-32.

\begin{abstract}
Recent archaeological surveys and excavations on the island of Atauro, East Timor, identified several rock shelters with evidence for prehistoric occupation. Well-preserved rock art was found at one of these sites, Aleti Tunu Bibi. Here we present a description of the site and rock art, including the motifs and design elements, and interpret the site within the context of East Timor and the wider Asia-Pacific region. Most of the art was painted in red (likely ochre) or, in a few circumstances, black pigment (likely charcoal). Ochre was found in Pleistocene and early Holocene layers during excavations of the site. The only observed drawing, the outline of a boat in dry black charcoal, may represent a "boat of the dead" similar to those depicted on Dongson drums in the region, one of which was found recently in East Timor. That a boat is depicted in the drawing suggests that it may have been executed sometime after 2000 B.P. The Aleti Tunu Bibi rock art fits within the description of other East Timor painted rock art and shares some attributes with other sites in East Timor. However, the Aleti Tunu Bibi rock art is also distinct from sites on the mainland, and its presence on Atauro Island supports previous hypotheses of substantial local or temporal variation, and possibly indicates a preAustronesian origin for this tradition on the island. KeYwords: rock art, Timor-Leste, Austronesian Painting Tradition, Pleistocene.
\end{abstract}

